\title{
Bio Management of Wilting of a Valuable Timber and Medicinal Plant of Shisham (Dalbergia sissoo Roxb.) - A Review
}

\author{
Narendra Kumar* and S. M. Paul Khurana \\ Amity Institute of Biotechnology, Amity University Haryana, Manaser-122413, \\ Gurgaon, Haryana, India \\ *Corresponding author
}

\begin{abstract}
A B S T R A C T
Keywords

Shisham, General uses, Medicinal uses, Fusarium, Chemical, Biological control

\section{Article Info}

Accepted: 07 December 2015 Available Online: 10 January 2016

Shisham is a medium to large deciduous(annually shedding the leaves) tree, native to India. It has a light crown and reproduces through seeds and suckers. The sissoo is best known internationally as a premier timber species of the rosewood genus. However, sissoo is also an important tree used for screen from direct sun light, provides cover or protection and feed for livestock. This lists the medicinal values of Dalbergia sissoo DC.(Fabaceae) for various ailments. The wood and bark of Sissoo have anthelmintic, antipyretic, expectorant, aphrodisiac abortifacient and refrigerant properties. Oil obtained from the seeds is used to cure diseases affecting skin.Like all other legumes it enhances the quality of soil due to presence of nitrogen fixing bacteria in roots. The leaves falling from the tree are also helpful in improvement of soil quality. It has been found showing severe wilting. The symptoms observed in all wilted plants are: yellowing and death of leaves in acropetal succession and lastly entire plant turns yellow. Pathogenicity test results revealed that both Fusarium solani and Fusarium oxysporum alone or either are highly potent causing severe wilting in plants. The article covers the chemical synthetic fungicides and biological control of Fusarium. This also deals about potential of Putranjiva roxburghii having volatile antifungal activity.The oil of Putranjiva roxburghii showed complete mycelial inhibition of both test fungi Fusarium oxysporum and Fusarium solani at 500ppm. The antifungal activity of oil was found thermostable even after autoclaving and storage (upto 120 days). The bark and root extract of Putranjiva was also found to be effective against both species of Fusarium. In this way this plant has an overall promise for control of Fusarium.
\end{abstract}

\section{Introduction}

Dalbergia sissoo (Indian Rosewood) is a deciduous tree, commonly known as sissoo, sheesham, tahli, Taland also Irugudujava. Tewari(1994) stated that it is native to the Indian Subcontinent and
Southern Iran and also found in tropical to subtropical Africa and Asia.Troup (1921) mentioned that, it is very likely that sissoo is indigenous only to the sub- Himalayan tract and has been introduced by man 
elsewhere. In Persian, it is called Jag. It is the state tree of Punjab state both both in India and the Pakistan. It is primarily found growing along river banks below 900 metres $(3,000 \mathrm{ft})$ elevation, but can range naturally up to $1,300 \mathrm{~m}(4,300 \mathrm{ft})$. The temperature in its native range averages $10-40{ }^{\circ} \mathrm{C}(50$ $104^{\circ} \mathrm{F}$ ), but varies from just below chilling to nearly $50^{\circ} \mathrm{C}\left(122^{\circ} \mathrm{F}\right)$. It can withstand a long period of abnormally low rainfall, especially one that adversely affects growing or living conditions of 3-4 months and average annual rainfall up to 2,000 millimetres (79 in). Shisham can grow in soils from pure sand and gravel to rich alluvium of river banks in slightly saline soils. Shisham is an important timber wood for furniture fuel, screen for direct sun light,provides cover or protection and feed for live stock. It usually cultivated in forest department plantations and along the manmade strip of water used for irrigation (canals), roadsides, railway lines, water channels and borders of the agricultural lands..

Review of literature highlights that wilt disease is caused by Fusarium solani (Mart) Wr. F.dalbergiae (Bagchee, 1945; Bakshi, 1954; Bakshi and Singh 1954,1959). Browne (1968)stated serious wilt of sissoo seedlings in nurseries caused by Fusarium oxysporum from Pakistan.

From time to time forest pathologists and other researchers viz.,Bakshi, 1954,Khan, 2000, Zakaullah, 1999,Khan and Khan, 2000) reported a number of diseases like powdery mildew, leaf rust, leaf blight, collar rot, wilting, die-back and Ganoderma root rot infections in shisham. Khan and Khan (2000) mentioned that Polyporus and Fusarium oxysporum cause root rot and wilting respectively. Fusarium solani was isolated as a facultative parasite associated with wounds and on hosts weekened by unfavorable conditions. This disease has reached epidemic proportion in Bangladesh and other countries of South Asia. The heart wood of plant is strong and durable and have high timber quality so it needs protection. Bakshi (1955) highlighted that elimination of pathogen from soil is not possible either chemically or by crop rotation. Synthetic pesticides pose a range of risks to human health and protection. There are three types of harmful effects caused by pesticides: acute effects, delayed effects, and allergic effects.

Acute effects are injuries or illnesses that appear immediately after exposure. The effects are usually obvious and capable of returning to an original condition if appropriate medical care is given right away. Delayed effects are illnesses or injuries that do not appear immediately. these include cancer. There are over 160 synthetic pesticides that are listed to be possible carcinogens. Many of these pesticides are still in use. The US EPA has classification systems that identify carcinogens. Pesticides have been known to cause asthma, breast cancer, leukemia, lymphoma and other immune system disorders.

Allergic effects are harmful effects that some but not all people develop in reaction to substances. These are responsible for environmental pollution. Biocontrol agents have been tried but they have their own limits.In nature plants are available which have broad spectrum antifungal and volatile activity that can completely suppress wilt causing fungal pathogens. Now a days, essential oil and their components are gaining increasing interest because of relatively safe status, their wide acceptance by consumers and their exploitation for potential multipurpose functional use (Ormancey et al.,2001; Sawamura, 2000; Tripathi and Kumar, 2007). 
The article deals the botanical description, systematic position, distribution, medicinal uses and highlights the work done on causal organism of shisham wilt and its possible management and the integrated strategies that can be used for the management of shisham plants.This also indicates the potential of putranjiva in mixed plantation in field for protection of shisham from wilt.

\section{Botany of Shisham}

\section{Plant Description}

This is a medium to large deciduous tree with a light crown which reproduces by seeds and suckers. It can grow up to a maximum of $25 \mathrm{~m}(82 \mathrm{ft})$ in height and 2 to $3 \mathrm{~m} \mathrm{(6 \textrm {ft }} 7$ in to $9 \mathrm{ft} 10 \mathrm{in})$ in diam. Trunks often got crooked when grown in the open. Leaves leathery, alternate,pinnately compound and about $15 \mathrm{~cm}$ (5.9 in) long. Flowers whitish to pink, fragrant, nearly sessile, up to $1.5 \mathrm{~cm}$ (0.59 in) long and in dense clusters $5-10 \mathrm{~cm}$ (2.0-3.9 in) in length. Pods oblong, flat, thin, strap-like 4$8 \mathrm{~cm}$ (1.6-3.1 in) long, $1 \mathrm{~cm}$ (0.39 in) wide and light brown. They contain 1-5 a smooth kidney-shaped seed, flattened at the sides, $8-10 \mathrm{~mm}$ (0.31-0.39 in) long. Sissoo has a long taproot and numerous surface roots which produce suckers. Young shoots drooping and downy; have established stems with light brown to dark gray bark to $2.5 \mathrm{~cm}$ (0.98 in) thick, shed in narrow strips; large upper branches support a spreading crown(Figure 1,2).

\section{Taxonomy}

Kingdom - Plantae; Unranked Angiosperma; Unraked Ecidicots; Unranked - Rosids; Order - Fabales; Family Fabaceae; Sub Family - Faboideae; Tribe Dalbergia; Genus - Dalbergia; Species Sissoo.

\section{Vernacular Names}

Sanskrit:Aguru, Shinshapa;Bengali:Shisu, Shishu, Sisu; English:Bombay Blackwood, Sissoo, Indian Rosewood, Sisso; Hindi: Agaru, Biridi, Tali, Gette, Kara, Shisham, Sisam, Sissai, Sissu, Sissoo;Tamil:Sisuitti, Sisso, Nukkukattai, Yette, Gette Thai:DuKhaek, Pradu-Khaek;Arabic:Dalbergia, Sissoo; Indonesian:Pradu-Khaek, DuKhaek; Javanese: Sonowaseso; Nepali: Sissau, Sisham; Spanish: Sisu; Trade name:Sissoo, Shisham

\section{Geographical Distribution and Suitable Conditions}

Distribution: Dalbergia sissoo Roxb. (Shisham) is native to the plains, low hills and mountain valleys of the sub-Himalayan region. It occurs naturally from sea level up to $1000 \mathrm{~m}$ msl sometimes even up to $1500 \mathrm{~m}$ msl, from the river Kabul in Afghanistan through northern Pakistan, northern India, Nepal, Bhutan and Bangla Desh and commonly planted throughout entire India,Pakistan and the Terai region of Nepal. It was successfully introduced to other parts of the Asian subcontinent as well as Southeast Asia, Africa, the Middle East, the Caribbean,North America, and Florida and Arizona in the United States.

Suitable conditions: It occurs naturally in riverine environments where sunlight and moisture are plentiful with annual rainfall averaging 500 to $4500 \mathrm{~mm}$. Temperature in native range varies from $4^{\circ}$ to $50^{\circ} \mathrm{C}$ and it is tolerant of light frosts but killed by low temperatures or long freezes. It grows well on rich alluvial soil, pure sand or gravel conditions with plentiful moisture and good drainage. It requires a $\mathrm{pH}$ of 5.0 to 7.7 and tolerates some salinity, but growth is stunted on heavy clayey soils. Natural regeneration is also common on newly exposed sites such 
as embankments, landslides, overgrazed areas and abandoned farmland.

\section{Propagation}

Propagation takes place most commonly by root suckers and also by seeds. The seeds remain viable only for a few months. Seeds should be soaked in water for 48 hours before sowing and $60 \%-80 \%$ germination can be expected in 1-3 weeks. Seedlings require partial sun or full sun.

\section{Chemical Constituents}

Following chemicals are isolated from various parts.

Leaves-Isoflavone-O-glycoside; FlowersBiochenin A, tectorigenin and 7-O- methyle tectorigenin; Green pods-Mesoinisitol, 7-Omethyle tectorigenin and 4'rhamnoglucoside; Mature pods-Isocaviumin, tectorigenin, dalbergin, caviunin and tannins; Stem bark-Dalberginone, dalbergin, methyl dalbergin and dalbergichromene; Heartwood-Dalbergin, nordalberginones, dalbergichromene, fixed oil and essential oils

\section{Uses of Shisham}

\section{General}

As timber: Shisham is best known internationally as a premier building/furniture timber species, but is also used as fuel wood and for shade and shelter from sunlight. With due tolerance of light frosts and long dry seasons, this species deserves higher consideration for tree farming, reforestation and agro forestry applications. It is the most important cultivated timber tree of Bihar after teak, which is the largest producer of shisham timber in India. In Bihar, the tree is planted on roadsides, along canals and as a shade tree. It is also commonly planted in southern Indian cities like Bangalore as a street tree.

Shisham is usually dried up before being used in furniture manufacturing. Locally Shisham is seasoned by keeping the logs for 6 month in wide open areas to dry up under the sun.. With hot air circulations it is dried for about 7 days to 15 days depending on weather conditions for commercial applicatons. Shisham is among the finest cabinet and veneer timbers and useful in preparation of 'Kartaals', the Rajasthani percussion instrument. This is also used for plywood, agricultural tools, carvings, boats, skis, flooring, etc.The heartwood is golden to dark brown; the sapwood, white to pale brownish white. Heartwood is extremely durable (the specific gravity is 0.7 -0.8 ) and is resistant to dry-wood termites; but the sapwood is readily attacked by fungi and borers. Mukherjee et al(1971) mentioned that Dalbergia sissoo contains the neoflavonoid dalbergichromene in its stem-bark and heartwood.

For fuel : The calorific value of both the sapwood and heartwood is 'excellent', being reported to be $4,908 \mathrm{kcal} / \mathrm{kg}$ and $5,181 \mathrm{kcal} / \mathrm{kg}$ respectively. Also makes good quality charcoal for heating and cooking.

For brushing teeth: Traditionally, slender twigs (called datun) are first chewed as a toothbrush and then split as a tongue cleaner. This practise has been in use in India, Africa, and the Middle East for centuries. It has been found that India's 80\% rural population still start their day with the chewing stick. Shisham twigs are still collected and sold in markets for this use and in rural India one often sees youngsters in the towns chewing on Shisham twigs. Bhambal et al. (2011) stated that it has been found to be equally effective as a toothbrush 
in reducing plaque and gingival inflammation.

\section{Toxic uses}

Adenusi and Odaibo (2009) found that ethanolic extract of the fruits of Dalbergia sissoo have molluscicide effect against eggs of the freshwater snail Biomphalaria pfeifferi. The percentage of dead embryos at the prehatch snail stage decreased while the deaths of embryos at the gastrula/exogastrula stage increased, with increasing concentration of extract. Lethality of the ethanolic extract of $D$. sissoo fruits to embryonated egg masses of B. pfeifferi is an added advantage to its potential development for use as a plant molluscicide.

\section{Medicinal uses}

In Ayurveda, various parts of Shisham tree are used for treating a variety of diseases (Table 1)such as leaves are used for eye pain,breast swelling, painful urination, gynaecological disorders and bleeding disorders. The paste of leaves mixed with sweet oil is useful in skin excoriation such as scrapping and abrading (Anupama, 2015). Herbs are not always safe. They may negatively affect body in certain conditions. Sissoo tree leaves wood and bark have abortifacient property, which means causing abortion. Therefore it must not be used during pregnancy.

\section{Recent work on medicinal uses}

The studies revealed that the tree is antiinflammatory, antinociceptive/reducing sensitivity to painful stimuli property, antidiabetic, analgesic and antioxidant properties as follows; Shazia et al(2006) surveyed on Indigenous knowledge of folk herbal medicines and it is useful in removing dandruff. Mohammad et al (2009) found Anti-inflammatory activity in ethanolic extract of Dalbergia sissoo (Roxb.) bark and concluded that the ethanolic extract of Dalbergia sissoo bark at $1000 \mathrm{mg} / \mathrm{kg}$ showed the most potent antiinflammatory activity. Jaspreet et al(2012) found analgesic and anti-inflammatory activities of Dalbergia sissoo leaf extract. Pankaj et al (2010)observed anti-diabetic activity of ethanolic extract of Dalbergia sissoo L. leaves and reported 12\% more effective in reducing the blood glucose level compared to standard Glibenclamide(also known as glyburide). Neeraj et al(2012) also evaluated anti-diabetic activity of of Dalbergia sissoo against alloxan induced diabetes mellitus in wistar albino rats and observed that ethanolic extract of Dalbergia sissoo bark possesses significant antidiabetic activity. Mallinath et al(2010)studied phytochemical and pharmacological properties of ethanol extract of Dalbergia sissoo seeds and reported the seeds to have moderate analgesic and remarkable antipyretic activities.

Nitinkumar et al(2011)found useful against helminths. Arvinder et al (2011)evaluated antioxidant potential of stem bark extract of Dalbergia sissoo. and reported chloroform extract possesses marked antioxidant activity, whereas methanolic extract has moderate activity.Mohammad et al (2011) reported antinociceptive activity in ethanolic extract of Dalbergia sissoo (Roxb.) bark. They reported that (300, 500 and $1000 \mathrm{mg} / \mathrm{kg}$ ) doses of extract exhibited significant and dose dependent antinociceptive activity possibly due to presence of flavanoids.Harsha et al(2012)observed anti-termite activity in heartwood of Dalbergia sissoo Roxb. Ex.Dc and concluded that the plant extracts can be used as an alternative for synthetic pesticides for termite control in 
buildings.Shisham tree is grown as shade tree for protection against direct sunlight along the roads. It increases quality of soil due to presence of nitrogen fixing bacteria in roots. The leaves falling from the tree are further helpful in improving soil quality/soil fertility.

\section{Wilting of Shisham}

\section{Wilting}

This refers to the loss of rigidity or flaccidity of non-woody parts of plants.It occurs when the turgor pressure in non-lignified plant cells falls towards zero due to loss or poor water retention in the cells. The loss of water retention by the plant has been found greater when the absorption of water and process of wilting modifies the leaf angle distribution of the plant (or canopy).

\section{Loss of water retention may be due to :}

Drought,where the soil moisture drops below conditions most favorable for plant functioning(ii)the temperature reaches to a point where the plants vascular system can not function and high salinity which causes water to diffuse from the plant cells and induce shrinkage(iii)saturated soil conditions, where roots are unable to obtain sufficient oxygen for set of metabolic reactions and processes that take place in the cells of organisms to convert biochemical energy from nutrients into adenosine triphosphate (ATP), and then release waste products and so are unable to circulate water into the plant; or(iv)bacteria or fungi that become blocked with an accumulation of thick wet matter in the plant's vascular system.

Wilting diminishes the plant's ability to transpire and grow. Permanent wilting leads to plant death. In woody plants, reduced water availability leads to blockage of the xylem.

Permanent wilting point (PWP) or wilting point (WP) is defined as the minimal point of soil moisture the plant need not to wilt. If moisture reduces to this or any lower point a plant wilts and can no longer recover its turgidity when placed in a saturated atmosphere for 12 hours. The concreate definition of the wilting point (symbolically expressed as $\theta_{\text {pwp }}$ or $\theta_{\mathrm{wp}}$ ) is defined as the water content at $-1500 \mathrm{~J} / \mathrm{kg}$ of suction pressure, or negative hydraulic head.This is defined as the percentage water content of a soil when the plants growing in that soil are first reduced to a wilted condition from which they cannot recover in approximately saturated atmosphere without the addition of water to the soil (Taiz and Zeiger, 1991).

\section{Symptoms Caused due to Fusarium Infection}

The Fusarium affects sissoo plants of any age group.Fusarium generally produces a condition in which leaves produce insufficient chlorophyll. As chlorophyll is responsible for the green color of leaves and chlorotic leaves are pale, yellow, or yellowwhite and death of most or all of the cells in an organ or tissue, premature leaf drop, browning of the vascular system. Fusarium wilt starts out looking like vein clearing on the younger leaves and drooping of the older lower leaves,preventing them from growing or proper development of the plant, yellowing of the lower leaves, defoliation, marginal death of most or all cells and death of the plant. On older plants, symptoms are found more distinct between the blossoming and fruit maturation stag es.(Figure 3,4).

Shisham mortality is spread throughout the Shisham zone, more severe in the Eastern Uttar Pradesh and Bihar in India. It falls 
under the category of causing tree decline diseases.

\section{Extent of Damage}

Trees of all ages and trunk-diameter classes are affected in the monoculture plantations. Mixed plantations show less signs of mortality. Mature trees of more than 50 years age are highly prone in Shisham plantations. Younger plantations of Shisham show too high \% mortality in some areas, particularly where biotic stresses, and erratic rainfall and extreme temperature variations/water-logging have occurred during recent years. Dead trees, partially dead trees as well as stumps that are not removed act as sources of infection.

\section{Factors for Shisham Mortality}

Unsuitable site selection is one of the main reasons of shisham decline.It grows well on well drained sites but not well in heavy texture soils (with more clay and silt content and less sand). Improper soil aeration in stiff and clayey soils cause death of fine/feeder roots due to asphyxiation besides water logging, even for a short duration, causes poor aeration and death of fine/feeder roots due to asphyxiation. Root disease pathogens enter through these dead roots (infection courts) and then attack living roots. Extended period of low temperature/freezes expose the trees to disease.The pressures resulting into weakening of tree vigour such as: - Injury to roots in agriculture (in fields) and construction activities (near roads, avenues) - Cleaning and weeding done through harrowing in plantations causing root damage - Covering of basal area with landfill, garbage and other material particularly on roadsides and urban areas Uncontrolled lopping in agriculture fields Blazing of bark for numbering of trees (on roadsides) - Injuries by cattle - Intentional girdling (on roadsides for removal). All these biotic pressures result into opening of wounds, site deterioration and overall weakening of vigour resulting into attack by the pathogens and decline/mortality.Bakshi (1955 and 1957) observed that higher moisture and water logging favoured an higher disease incidence. Irrespective of stress conditions across tree girth, maximum incidence was recorded in treees with 51$100 \mathrm{~cm}$ girth followed by $101-150 \mathrm{~cm}$ girth. This shows that younger trees were more susceptible to disease than older and higher girth trees. Dayaram et al(2003)reported many stress factors such as waterlogging, flooding, semi-flooding, drought, degraded soil, uncareful ploughing, high density and high moisture and waterlogging caused 73.1 $\%$ disease whereas, high irrigation alone caused $13.8 \%$ incidence. Flooding, semiflooding, degraded soil, uncareful ploughing and high density and moisture caused 27.4, 52.1, 27.6, 30.2 and $41.1 \%$ incidence, respectively.

\section{Work Done on Causal Organism and Pathogenicity}

The Shisham or Indian Rosewood tree is a much-prized tree, cultivated for its timber.But it is highly susceptible to a disease called wilt caused by fungi which target particular species. Two pathogens have been found responsible for shisham mortality - Fusarium solani f. sp. dalbergiae causing vascular wilt and Ganoderma lucidum causing root rot. The former was found wide spread throughout shisham growing area whereas $G$. lucidum is associated in drier localities such as Haryana and Punjab. Virulent and avirulent strains of Fusarium solani f. sp. dalbergiae exist. The pathogen moves up the stem from the roots. Parker (1918) investigated that Fomes lucidum attacks the roots of living sissoo trees and speedily cause their death. The 
much more dangerous fungus is Fomos lucidus which is responsible for high mortality of sissoo trees (Troup 1921). Bakshi (1956)highlighted Fusarium solani is responsible for causing wilt and death of sissoo. The infection occurs through roots from where the fungus proceeds along the stem to some extent. Khan and Bokhari (1970) reported that the commonest pathogens of sissoo is Fomes lucidum, a root and heart rot fungus that causes extensive damage once it is established. The other fungi which affect sissoo are Poria ambigua and Polyporus gilvus which cause die-back and canker.

Bakshi(1954) said that Shisham is an important timber species of North India.It has been found to suffer from wilt disease in the Dehra Dun and Saharanpur districts in western Uttar Pradesh. The disease occurs both in natural forests and in taungyas which are artificially regenerated with field crops in admixture with other economic species like semal (Bombax malabaricum), babul (Acacia arabica), khair (Acacia catechu), bamboo (Dendrocalamus strictus), etc. Only trees of about 15-25 years old suffer from this disease but wilting has not been observed in the seedling, sapling and pole stages of the plant. The symptoms of wilt in shisham are systemic and are characterized by drooping leaves and branches due to loss of turgor. The leaflets gradually turn, yellow, and eventually drop off. The entire tree becomes 'thin' and light coloured, and stands out sharply in contrast to adjoining densely clothed green healthy trees. The nodules and slender branches on roots which characterize healthy shisham are absent on the roots of wilted trees. On splitting the diseased roots, the bark and the outer sapwood exhibit a well-defined, pinkishbrown, stain, and though the stain is restricted in this region, it may rarely penetrate into the inner sapwood. The heartwood is free from the stain. The stain also progresses along the outer sapwood from the roots to the stem and, in the late stage of wilt, it may extend up the stem to about ten feet from the ground(Bakshi,1954).

In the irrigated plantations in Bhagat in Punjab, Khan and Bokhari (1970) reported that nearly 1 tree/acre was found diseased out of the 74 standing trees. The total yield in all the fellings decreased by $21 \%$. In financial terms, the loss was about $31 \%$ of the total expected income. Out of the $8 \%$ of diseased sissoo trees, the common pathogens were Ganoderma lucidum $(7.85 \%)$ and Poria ambigua (0.45\%). The cumulative rate of loss in 20 years came to be more than $28 \%$.The wilt disease gets manifested during the months of September -.November both in India and Bangladesh during humid months from July to September (Sharma et al., 2000; Baksha and Basak, 2000).

Shakir et al. (1999) investigated F. solani from diseased roots and assumed this organism to be the cause of shisham decline. Baksha and Basak (2000)observed a wide spread mortality of shisham trees of varying ages in Bangladesh and assumed that $F$. solani and shothole borer may be the cause of disease. Earlier, Bakshi (1957) also isolated $F$. solani from diseased shisham plants. The fungal hyphae and jelly like substances plug the vessels resulting in wilt symptoms (Bakshi and Singh, 1959). Davis et al. (1953) found that wilt is generally the result of Fusarium attack at the roots or even lower portions of stem where its growth interferes with the safe passage of water and excreted toxins. According to some workers, Fusarium oxysporum is the cause of shisham wilt (Gill et al., 2001). Dieback is caused by Phytophthora cinnamomi (Gill et al., 2001). Some people confuse the wilt with dieback. Dieback is entirely different disease 
characterized with thinning of leaves and crown, drying up of the ends of branches, table topped condition and stag-headness in extreme conditions (Khan and Khan, 2000).

Bajwa et al (2003)stated that shisham tree has been inflicted with dieback and wilt diseases in the recent years and the \%incidence is also reported in Tarai tract of Nepal, believed to be its home.The characteristic symptoms of shisham wilt were yellowing and death of leaves in acropetal succession up the tree, as a result the whole tree appears yellow. In advanced stages the affected trees show signs of wilting, the leaf shed rendering the branches bare, and ultimately plants die within a few months. Older trees are usually found to be more prone to mortality. The outer sapwood shows characteristic pink to reddish stain. Though it is normally restricted to outer sapwood, sometimes it penetrates in the inner sapwood yet, the heartwood is not discoloured. The stain progresses along the outer sapwood of the root to the stem and in later stages of wilting it extends up the stem to about 3-5 $\mathrm{m}$ from the ground.

Dayaram et al(2003) observed twenty districts of North Bihar to study the extent and causes of shisham mortality. Highest disease incidence was recorded in Araria district $(80.0 \%)$ followed by Katihar (78.0\%). Lowest disease incidence (35.4\%)was recorded in Darbhanga followed by Khagaria (41.6\%).60.5\%disease was recorded in plants having $51-100 \mathrm{~cm}$ girth followed by plants $101-150 \mathrm{~cm}$ girth (48.7\%).Waterlogged condition aggravated the disease incidence. Fusarium solani 1. sp. dalbergiae has been confirmed as the pathogen. Abiotic stress conditions viz.; waterlogging, flooding, semiflooding, drought, degraded land etc. were also recorded during survey. Plant parts as well as rhizosphere soil samples of infected alive and dead shisham trees were collected and brought to laboratory for analysis to establish the cause of mortality. Symptoms and per cent incidence were recorded in the field. On the basis of girth the infected trees under all stress conditions were categorised into $0-50,51-100,101-150,151-200,201-$ 250, 251-300 and 301- $350 \mathrm{~cm}$ (circumference at breast height) classes. Rhizosphere soil samples of infected shisham trees were analysed to study any relationship of mortality with the $\mathrm{pH} \& \mathrm{EC}$ Three types of disease symptoms were noted in naturally wilting trees. Green tree showed sudden wilting tendency with complete leaf drooping and drying from top of tree. After 15-20days dried leaves fall off from the branches. The branches start drying from the top and the plants dry within 3 months. Sometimes after leaf fall, new small leaves and some new shoots appear but wilting appears again within 3-4 months. Such plants die within 2-3 $\mathrm{m}$ after second infection. Slow wilting and yellowing symptoms were observed in upland plantations as compared to low land and waterlogged plantation conditions. First, the green leaves turned yellow and then branches dried down slowly from top to bottom and showed complete drying in 9-12 months. Some times partial wilting of tree occurs and the healthy part remains alive for a longer period. It takes normally 2-3 yr for complete death/drying of plant.

Rukshana and Javaid (2007)observed that in Punjab trees were severely suffering from wilt and dieback diseases. Maximum mortality of up to $80 \%$ was observed along the canal bank followed by $20-40 \%$ along the highways and roadsides. The least disease incidence and mortality rate was observed in plants growing on agricultural and well managed lands. Generally the older plants were found to be more susceptible to dieback attack than the younger ones. 
However, wilt was common both in young and old plants. Stressed conditions either drought or high soil moisture content were found to be helpful for attack of pathogen and severity of the disease. F. solani (Mart.) Appel \& Wr. was isolated from the roots of shisham plants suffering from wilt disease.Rajput et al (2008) isolated Fusarium solani from shisham dieback trees.Internal browning of stem and roots were rated on 0 5 scale. Shisham plants inoculated with $F$. solani alone produced maximum disease incidence, showed prominent typical symptoms of the disease with internal browning of stem and roots. However, $R$. solani and $C$. lunata either completly failed or caused very rare infection on test plants. $F$. solani produced moderate infection on shisham seedlings when inoculated with either $R$. solani or $C$. lunata. Maximum reduction in root and shoot length was observed in plants inoculated by injecting spore suspension of $F$. solani as compared to spore suspension added to soil or plants sprayed with spore suspension. Root and shoot weight also decreased when spore suspension of $F$. solani was injected into stem followed by soil amended with spore suspension and plants sprayed with spore suspension. Similar trends were also observed about reduction in whole plant growth and weight. Host range studies coducted by inoculating seedlings each of 10 different trees with $F$. solani indicated that the test fungus was moderate to highly pathogenic to shisham, Indian laburnum, siris and gold mohar.

Bhandari et al(2014)mentioned that the genetic diversity in shisham is very low; which is the reason for increased attack by diseases and insect-pests. The species is eclipsed with one of the most important disease called dieback wilt by $F$. solani f. sp. dalbergiae. The biotic and abiotic factors help in the spread of pathogen. In the plantation trial at Hoshiarpur (Punjab) the dieback wilt causes a tremendous damage to the standing trees.Mortality was found highest $(7.65 \%)$ for the experimental trials of shisham that includes a total of 49 clones and rametes. The disease was spreading rapidly and affecting other healthy plantations in the trial.

Kumar(2014)investigated wilting in North Eastern Uttar Pradesh and his survey registered more than $30 \%$ wilted plants.It was found that wilting is highly alarming in Basti district with 50-60\%wilting in the month of July followed by Siddharthanagar,Santkabirnagar and Gorakhpur district(Table 2).Wilted plants were observed in all age groups,in nursery,5-10 year,10-15year,15-20year,3040year with yellowing and death of leaves in acropetal sucession and lastly death of entire plant in humid months from July to September. 16 fungal species were found to be associated with sterilized and unsterilized root pieces. The per cent occurrence of Fusarium oxysporum in Basti, Santkabirnagar, Siddharthanagar, Gorakhpur district was found to be $80.4,80.3,78.6$, 53.6 per cent respectively and that of Fusarium solani was 79.4,79.3,79.0 and54.8 per cent respectively. On pathogenicity $F$. oxysporum showed $70 \%$ wilting while F.solani showed $80 \%$ wilting while control set showed no wilting.

\section{Mechanism of Wilting}

The production of microconidia takes place in great quantity and may be either oval, elliptical or kidney shaped and produced on any portion of mycelium growing above the nutrient medium as aerial mycelia. Macroconidia(three to five celled), gradually pointed or curved edges and found on sporodochia on the surface of diseased plant (in culture the sporodochia may be sparse or 
nonexistent). The Chlamydospore formation takes place either singly or in pairs, but can sometimes be found in congregate or in short row. Being thick walled spores they are produced within or terminally on an older mycelium or macroconidia. In comparison to other types, chlamydospores can survive in the soil for a long period.

F.oxysporum is a common soil pathogen and saprophyte that feeds on decaying matter composed of organic compounds or the remains of organisms such as plants and animals and their waste products. This fungus flourishes in the soil laden mass of loose mud, sand, soil, rock etc as mycelium having all spore types, but mostly the chlamydospores. Its spread occurs in two basic ways: to short distances by air moving in a certain direction and also instruments used in plantations and to long distances by infected materials and seeds. F. oxysporum invades and proliferates in a healthy plant by means of mass of hyphae or by germinating spores penetrating the root tips, root wounds, or lateral roots extending horizontally to anchor the plant securely into the soil. The overall plant physiology gets inhibited due to mass of hyphae going intracellularly through the root cortex reaching up to xylem. In the xylem, the mass of hyphae remains exclusively in the vessels and produce microconidia which have capacity to enter into the sap stream and get transported upward. Due to the presence of dissolved sugars and minerals in the circulatory system the microconidia germinate. Eventually the vascular vessels become blocked with an accumulation of thick mass of hyphae and spores.This prevents the plant from up-taking and translocating nutrients. Lastly the plant transpires off water vapour through the stomata much more than it can transport and the stomata get closed, the leaves wilt and resultantly the plant dies. The fungus invades all tissues, sporulates well and continues to infect neighbouring plants.

\section{Management of Wilting}

\section{Steps for Control}

Khan et al. (1965) highlighted that mortality of sissoo is the result of physiological problem brought about by soil-cumirrigation factors. The temperature and wind play an indirect role. Remedial measures suggested were artificial application of more water to the land or soil and changing of plantation make up/maintenance schedule.

Although the cause of die-back problem has not been clearly understood still a number of following remedial measures can be taken to prevent or minimise the disease;Avoid Injury - It was observed that mostly trees grown along water channels got infected as compared to the scattered ones. It was found that during the cleaning water channels, roots of the trees got injured helping easy entry of pathogens. Possibly that frequent inter cultivation also increases the chances of root injury. Which should be restricted after establishment of trees(Khan et al. 1965).

Selection and preparation of site - Raise shisham on a site having light textured soil with adequate soil moisture and good drainage. Avoid hard clayey soils with tendency of water logging.; Mixed Cropping - When growing two crops intermingled together in the same field, the incidence of infection is usually low. Introduction of resistant plants such as Acacia nilotica Mours spp., and Eucalyputs spp is also recommended. Avoid pure plantation of shisham and have them mixed preferably with nonleguminous species. 


\section{Sanitary Precautions}

The infected stumps must be removed from the ground as they may spread pathogen to healthy trees. In areas used for sissoo planting, all effort must be made to free the ground completely of dead and decayed wooden fragments and fungal fruiting bodies which are ready source of infection. Deep wounds should be covered with grafting wax and rubber latex. This will not only allow the timely utilization of the timber from the dead trees but also check the spread of the pathogen to the adjacent trees.;

\section{Deep Planting}

In dry locations deep irrigation is recommended so trees can develop deep root systems which can draw water from the water table when irrigation is stopped. In addition sowing of seeds and a deep planting hole are recommended to help,develop long tap root, which may reach capillary zone of sub soil water within 2-4 years. (Khan $e t$ al. 1965)

\section{Ban on Debarking}

Complete ban or debarking should be forced.

\section{Site Selection}

Elimination of the pathogen (F.solani) from the soil is not possible either chemically or by growing different crops in succession on a piece of land to avoid exhaustion of the soil and to control weeds,diseases and pests. Therefore selection of light textured soil having adequate soil moisture and drainage is important.

\section{Removal of Over-aged Trees}

Wilting trees of more than 45 years age should be removed. It will reduce further spread of infection and also termite problems.

Selection of Resistant Clones and Propagation - Resistant material has been devloped by Forest Research Institute and should preferably be used for future plantations. However, selection of resistance is a continuous process. Bajwa and Javaid (2007) advocated that Resistant shisham varieties should be planted on well drained sandy loam soils to control wilt and dieback. The severely infected and dead plants must be uprooted followed by disinfection of the soil to avoid further spread.

Control Biotic Pressure-The biotic pressure on shisham can be reduced by developing alternate forest area as buffer zone.The extensive village eco-devlopment programme will also help to reduce the biotic pressure.Field staff should also be sent to other plantaions to gain first hand information.

\section{Integrated Disease Management-}

According to present literature the management can be achieved as follows-

\section{Chemical Management}

Khan et al.(1965)found that carbendazim (Bavistin) and captaf (captan) fungicides are very effective against $F$.solani.. Ahmad et $a l$, (1996) mentioned that among the three fungicides evaluated against $F$. solani in vitro, Benomyl was found to be highly effective causing a significant reduction in mycelial growth even in very low concentration of $10 \mathrm{ppm}$. Ridomil was effective but at higher concentration. Some other fungicides such as Vitavax, Dithane M-45, Bavistin are also known to have significant suppressive effect on growth of $F$. solani. Benomyl, the most effective fungicide in in vitro also proved very 
effective in vivo and this fungicide may prove highly beneficial to save the shisham trees from wilting. In an experiment all the three shisham plants, which were likely to be dead by wilting during next few weeks, managed to recover themselves from disease after treatment with Benomyl. However, there is need to study its effectiveness against the wilt attack in older trees. Bajwa and Javaid(2007)found that Benomyl was effective in controlling wilt in 6-8 years old shisham plants. It is a stable fungicide suitable for injection into the trees (Mcwain and Gregory, 1973). A benomyl derived fungus toxicant MBC (Methyl-2-benzi midazol carbamate) is also known to be effective against wilting.

\section{Biocontrol Agents;Fungi}

Bajwa and Javaid(2007)investigated that Shisham decline can be controlled by adopting integrated disease management (IDM) approach. Trichoderma harzianum Rifai, $T$. viride Pers. ex Gray and $T$. aureoviride Rifai can be used as biological control agent to reduce the field inoculum of F. solani.

\section{Biocontrol Agents;Bacteria}

Czaczyk et al (2002) reported the antifungal activity of Bacillus coagulans against three pathogenic species of Fusarium by checking colony forming units, dry matter and ergosterol level and biosynthesis of Fusarium mycotoxins. Estimation of ergosterol level as a determinant of fungal growth showed the greatest degree of Fusarium sp. inhibition. Addition of Bacillus coagulans to Fusarium culmorum culture inhibits the DON (deoxynivalenol) production. Jun Yuan et al (2012) found that Bacillus amyloliquefaciens NJN-6 produces volatile compounds (VOCs)inhibiting growth and spore germination of Fusarium oxysporum f. sp. cubense. Out of 36 volatile compounds detected, 11 compounds completely inhibited fungal growth. The antifungal activity of these compounds suggests that VOCs can play important roles over short and long distances in the suppression of $F$. oxysporum. The VOCs produced by NJN-6 strongly antagonized $F$. oxysporum in soil and the quantity of $F$. oxysporum in the treated soil was $10^{2} \mathrm{~g}^{-1}$ after 45 days as against $10^{4} \mathrm{~g}^{-1}$ in the control soil. Previous research has shown that abundant nutrients in the soil increased the production of bacterial VOCs, suggesting that the amount of organic matter in the soil might affect the ability of NJN-6 to release VOCs into the soil. Nonvolatile antibiotics, including lipopeptides, have strong antifungal activities. However, these nonvolatile antibiotics cannot spread over long distances and only when these antagonists directly colonize the plant roots they can prevent pathogenic fungi from infecting plants. In contrast, VOCs can spread over a long distance and fungistatic microenvironments exist around the antagonist communities. In addition, the antifungal VOCs produced by bacteria can kill surviving spores in the soil and limit both the production, spread and the establishment of the disease.

\section{Management with Broad Spectrum Antifungal Plants}

Since Fusarium has very wide host range causing wilt in many plants,hence pathologists have often tried for finding antifungal activity in plants to devlop ecofriendly management of wilts which is as follows-

Antifungal activity of different concentrations $(2,4,6$ and $8 \% \mathrm{w} / \mathrm{v})$ of leaf extracts of wheat (Triticum aestivum L.), maize (Zea mays L.), sunflower (Helianthus 
annus L.), chilies (Capsicum annum L.), onion (Allium cepa L.) and marigold (Tagetes erectus L.) was evaluated in vitro for checking growth of $F$. oxysporum. Extract of marigold, sunflower and chilies were found highly effective having reduced fungal biomass by 54- 79\%, 33-85\%, 45$57 \%$, and onion by $73 \%$ respectively(Tariq Riaz, et al.,2008). Sharma and Kumar (2009)also tried for the development of ecofriendly antifungal compounds for controlling plant diseases caused by F.oxysporum through extracts of three weeds namely Capparis decidua, Lantana camara and Tridax procumbens. The spore germination/spore counting technique was followed for the evaluation of the fungicidal properties of the extracts at three different concentrations. Results revealed that the free flavonoids and sterols of $T$. procumbens (flower) and bound flavonoids of $C$. decidua (fruit and stem) totally inhibited spore germination of the fungi (100\%). The antifungal components from these plants could be used in developing novel fungicides (biopesticides). Asha et al(2009)assessed avtivity of the crude extracts of six plants viz, Allium sativum, Capsicum annuum, Artimisia vulgaris, Eupatorium adenophorum, Gaultheria fragrantissima and Phyllanthus emblica against $F$. solani (Mart.) Sacc. The extracts of all the plant species were effective in inhibiting the mycelial growth. Jasenka et al (2010)observed potency of essential oils (clove, rosemary, cinnamon leaf, sage, scots pine, neroli, peppermint, aniseed, caraway, lavander, common thyme)for in vitro antifungal activity on twelve plant pathogenic fungi (Fusarium graminearum, $F$. verticillioides, $F$. subglutinans, $F$. oxysporum, $F$. avenaceum, Diaporthe helianthi, D.phaseolorum var. caulivora, Phomopsis longicolla, P. phaseolorum var. caulivora, P.longicolla, P. viticola, Helminthosporium sativum, Colletotrichum coccodes, Thanatephorus cucumeris). The results indicated that all oils except scots pine and neroli had antifungal activity against some or all tested fungi. The best antifungal activity was in common thyme, cinnamon leaf, clove and aniseed oils(Jasenka et al.,2010).

Sirirat (2010)evaluated essential oil of Trachyspermum ammi Lin.against three strains of F.oxysporum. F. oxysporum f.sp. lycopersici, F.oxysporum f.sp. cubense and $F$. oxysporum f.sp. capsici the wilt pathogen of tomato, banana and chili respectively. The in vitro assay (based on poison food method) indicates that ajowan(Trachyspermum ammi) oil, in solution phase, possesses strong antifungal activity against the test fungi. The Minimum Inhibitory Concentration (MIC) and the Minimum Fungicidal Concentration (MFC) were 240 and $480 \mu \mathrm{g} \cdot \mathrm{mL}-1$, respectively. The antifungal activity of volatile headspace of the essential oil was evaluated under a modified atmosphere in inverted Petriplates. Headspace vapor of ajowan oil has a strong activity with Minimum Inhibitory Quantity (MIQ) and the Minimum Fungicidal Quantity (MFQ) of 12.5 and 25.0 $\mu \mathrm{l}$, respectively. Additionally, the effects of ajowan oil on the biomass production and sporulation of the test fungi indicate that it has significant retardation effect on the biomass production and sporulation of the fungi. Results suggested that ajowan oil has potential use as a biofungicide against the wilt pathogens.

Al-Hetar et al(2011)investigated the in vitro antifungal activity of chitosan against Fusarium oxysporum f. sp. cubense Race 4 (FocR4) the causal agent of banana wilt.Chitosan at all concentrations tested reduced the hyphal growth of FocR4 on potato dextrose agar media and registered maximum inhibition of $76.36 \%$ at $8 \mathrm{mg} / \mathrm{mL}$. 
Table.1.Medicinal uses of Various Parts of Shisham

\begin{tabular}{|c|c|c|}
\hline Plant parts & Preparation & Problem \\
\hline \multirow{6}{*}{ Leaf } & $\begin{array}{l}\text { Juice mixed with honey as eye } \\
\text { drop }\end{array}$ & Pain in eyes \\
\hline & $\begin{array}{l}\text { Leaf juice in dose of } 10-15 \mathrm{ml} \\
\text { thrice a day }\end{array}$ & $\begin{array}{l}\text { Jaundice,pus in } \\
\text { urine }\end{array}$ \\
\hline & $\begin{array}{l}50-100 m l \quad \text { decoction of } \\
\text { leaves,drink twice a day }\end{array}$ & $\begin{array}{l}\text { Painful urination,boils, } \\
\text { pimples, blood } \\
\text { purification }\end{array}$ \\
\hline & $\begin{array}{l}\text { Warmed and tied on affected } \\
\text { area for reducing swelling }\end{array}$ & Breast swelling \\
\hline & $\begin{array}{l}\text { 10-15 ml juice of leaves twice a } \\
\text { day }\end{array}$ & Pain in abdomen \\
\hline & $\begin{array}{l}\text { Juice in dose of } 10-15 \mathrm{ml} \text {,twice in } \\
\text { a day }\end{array}$ & $\begin{array}{l}\text { Abnormal bleeding } \\
\text { in females }\end{array}$ \\
\hline \multirow{4}{*}{ Bark powder } & $\begin{array}{l}\text { 3-6 grams with one cup } \\
\text { milk/water for } 2-3 \text { weeks }\end{array}$ & Body pain \\
\hline & 3-6 gm decoction & Gonorrhoea \\
\hline & $\begin{array}{l}\text { 10gm sissoo bark boiled in } \\
500 m \text { of water till the volume } \\
\text { reduces to half, mix the juice } \\
\text { and consumefor } 40 \text { days every } \\
\text { morning }\end{array}$ & Leprosy \\
\hline & $\begin{array}{l}\text { Bark powder } 1 \mathrm{~kg} \text { cooked in } 2 \\
\text { litre water, taken in dose of ten } \\
\text { grams with milk } 3 \text { weeks }\end{array}$ & Sciatica \\
\hline Shisham oil & Topical application & Skin diseases \\
\hline
\end{tabular}

Table.2 Percent Wilting of Sissoo Tree in Different Districts of Eastern U.P during July(Kumar,2014)

\begin{tabular}{|l|l|l|l|l|l|l|l|}
\hline $\begin{array}{c}\text { Name of Place } \\
\text { (District/village) }\end{array}$ & $\begin{array}{l}\text { Per cent } \\
\text { wilting }\end{array}$ & $\begin{array}{l}\text { Name of Place } \\
\text { (District/village) }\end{array}$ & $\begin{array}{l}\text { Per } \\
\text { cent } \\
\text { wilting }\end{array}$ & $\begin{array}{l}\text { Name of Place } \\
\text { (District/village) })\end{array}$ & $\begin{array}{l}\text { Per } \\
\text { cent } \\
\text { wilting }\end{array}$ & $\begin{array}{l}\text { Name of Place } \\
\text { (District/village) }\end{array}$ & $\begin{array}{l}\text { Per } \\
\text { cent } \\
\text { wilting }\end{array}$ \\
\hline $\begin{array}{l}\text { Basti } \\
\text { Jamdi Road }\end{array}$ & 51 & $\begin{array}{l}\text { Santkabirnagar } \\
\text { Sameriwa }\end{array}$ & 30 & $\begin{array}{l}\text { Siddharthanagar } \\
\text { Dumariaganj }\end{array}$ & 42 & Gorakhpur & Bhiti Road \\
Mahsoo Road & 55 & Nandor & 39 & Hallore & 40 & Sahjanwa & 31 \\
Sonupar area & 60 & Lohrauli & 30 & Itwa tahsil & 44 & Ghagsara & 32 \\
Munderava & 50 & Mangua Road & 39 & Bansi & 40 & Khajani & 33 \\
Orwara & 54 & Khalilabad & 38 & Naugrah & 49 & Pipraich & 29 \\
\hline
\end{tabular}


Table.3 Evaluation of Essential Oils against F. Oxysporum and F.Solani(Kumar,2014)

\begin{tabular}{|l|l|l|l|}
\hline \multirow{2}{*}{ Plant species } & \% inhibition of mycelia growth of test fungi at 500ppm \\
\cline { 2 - 4 } & Family & Fusarium oxysporum & Fusarium solani \\
\hline Aegle marmelos $($ L.)Corea & Rutaceae & 37.3 & 62.1 \\
\hline Ageratum conyzoides L. & Asteraceae & 70.5 & 64.2 \\
\hline \multicolumn{1}{|c|}{ A. Houstonianum L. } & - & 80.5 & 80.5 \\
\hline Anisomeles ovata R.Br. & Lamiaceae & 60.3 & 60.3 \\
\hline $\begin{array}{l}\text { Artabotrys } \\
\text { hexpetalous }(\text { Lamm)Merr. }\end{array}$ & Annonaceae & 54.2 & 46.7 \\
\hline Feronia elephantum Correa & Rutaceae & & \\
\hline F.limonia L. Swingle & - & 59.7 & 60.3 \\
\hline Mentha piperata L. & Lamiaceae & 60.8 & 65.4 \\
\hline M.spicata L. & - & 60.3 & 50.3 \\
\hline Ocimum adscendens Willd & Lamiaceae & 63.3 & 48.2 \\
\hline O.basilicum L. & - & 50.0 & 52.4 \\
\hline O.canum Sims & - & 45.1 & 50.1 \\
\hline O.sanctum L. & - & 55.1 & 75.0 \\
\hline Putranjiva roxburghii Wall & Euphorbiaceae & 47.1 & 52.3 \\
\hline & & 100 & 100 \\
\hline
\end{tabular}

Figure.1.Stem with Leaves

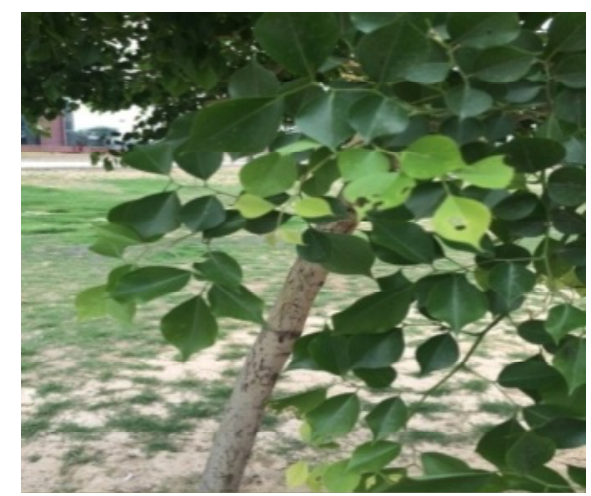

Figure.2 Pods of Sissoo

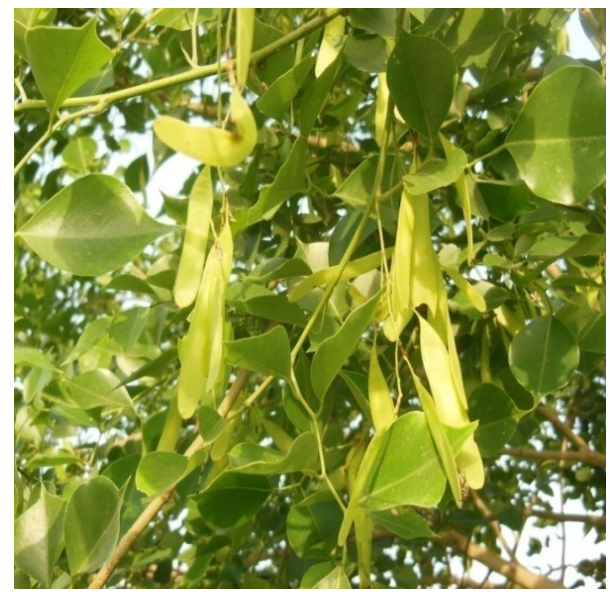


Figure.3 Wilting in 40-45 Year Old Tree of Shisham

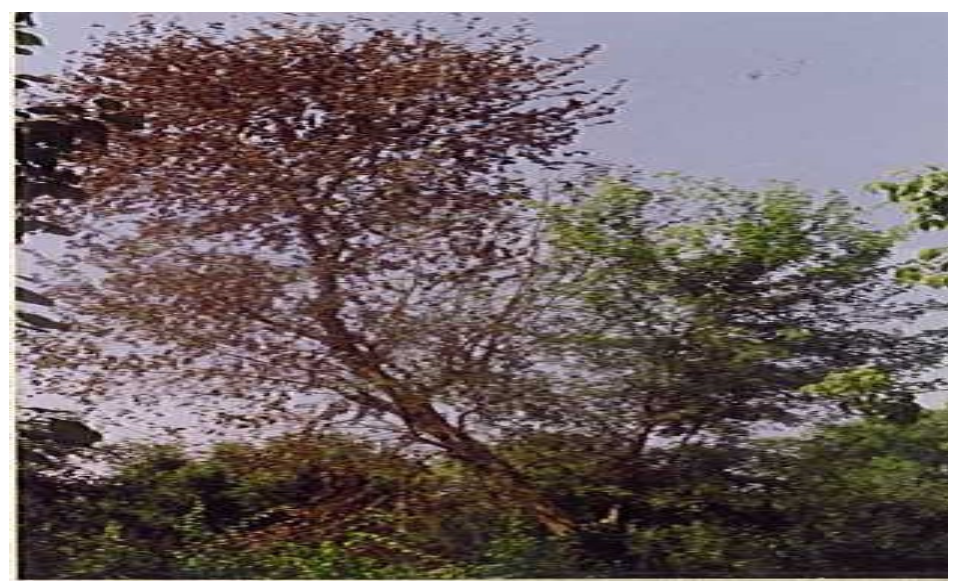

Figure.4 Wilting of Shisham Trees in a Row Plantation along with Healthy Tree

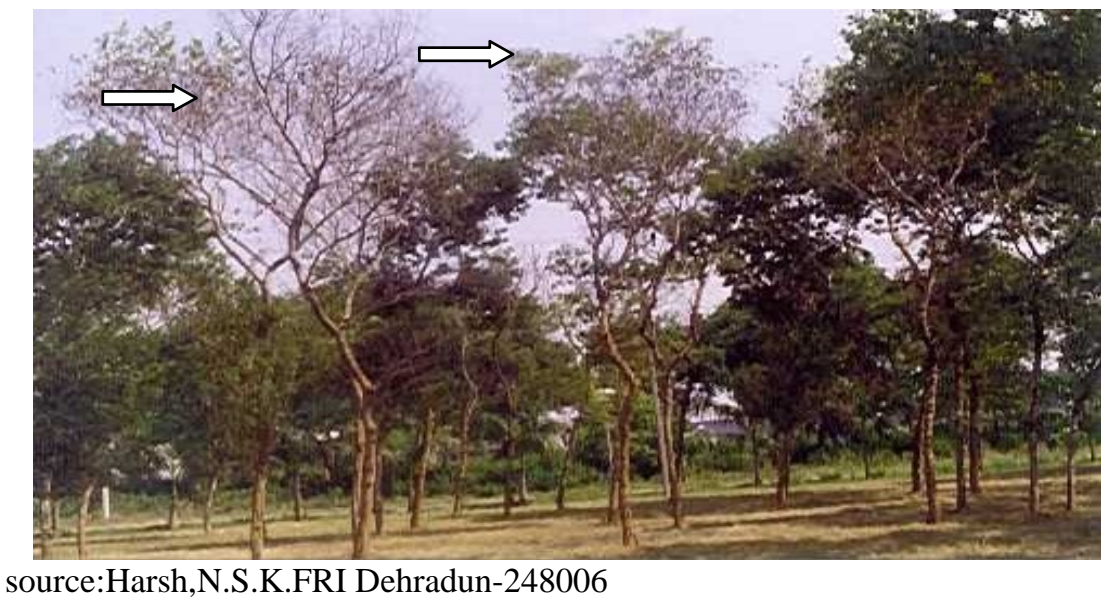

The inhibitory effect was found to increase as chitosan concentration increases. The $50 \%$ effective concentration value was estimated by probit analysis, and it was 1.4 $\mathrm{mg} / \mathrm{mL}$. Chitosan was more effective in potato dextrose broth where it completely inhibited the mycelial growth of FocR4 at all concentrations tested. Chitosan inhibited the sporulation of FocR 4 by a maximum of $96.53 \%$ at $8 \mathrm{mg} / \mathrm{mL}$ chitosan, and $100 \%$ inhibition of spore germination was recorded at all concentrations tested. Chitosan at concentrations of more than 1.6 $\mathrm{mg} / \mathrm{mL}$ was also found to induce morphological changes in FocR4 characterized by agglomeration of hyphae, abnormal shapes, vesicles, or empty cells devoid of cytoplasm in the mycelia.

Sibounnavong et al(2012) found that antagonistic fungi Chaetomium brasilense CB01 and Chaetomium cupreum CC03 antagonized F.oxysporum f.sp. lycopersici NKSC02 race 2 that caused tomato wilt of sida abd cherry varieties. The bioactivities test demonstrated the antagonistic activity of Ch. Brasilense CB01 and Ch. Cupreum CC03 inhibited production of $F$. oxysporum f. sp. Lycopersici race 2 conidia.Tongbram et al(2012)investigated the antifungal effect of aqueous extracts of locally available plant species in vitro conditions against $F$. 
udum, the causal agent of Fusarium wilt of pigeonpea. Among the plants tested higher inhibition was noticed in Allium sativum, Azadirachta indica, Spilanthes acmella and Adhatoda vasica. In field experiment, aqueous extract of $A$. sativum showed maximum disease control. Rosado-Álvarez et al (2014) observed a significant inhibition of mycelial growth and sporulation of $F$. oxysporum f. sp. asparagi, $F$. oxysporum $\mathrm{f}$. sp. dianthi and $F$. oxysporum pathogenic to strawberry upon addition of the asparagus extract. The latest research of Kamel et al(2015)suggested that haliscosamine is a potential candidate against $F$. oxysporum f.sp. melonis and with the possibility to use in phytopathology. Kumar(2014)also reported bioactive potential of the essential oil of Putranjiva roxburghii Wall with absolute fungal toxicity at 500ppm. (Table 3)following inverted petri plate technique against wilt pathogens causing wilt in shisham.The MIC of the oil was found to be $500 \mathrm{ppm}$ against both the test fungi. The root, bark and seed extract of Putranjiva showed $100 \%$ mycelial inhibition of both test fungi at 1;10 dilution. A small pilot experiment at nursery level upto two year as a mixed plantation of sissoo and Putranjiva showed complete protection of wilting. So in order to protect sissoo Putranjiva may be used against Fusarium after successful large scale mixed planation field trials. The monoculture concept for sissoo need to be discouraged because shiham wilt now in epidemic stage.

In conclusion, Sissoo is an important timber and effective medicinal tree various diseases. The wood and bark of Shisham have abortifacient, anthelmintic, antipyretic, aphrodisiac, expectorant and refrigerant properties and used much for treatment of wounds and gonorrhoea. Shisham wilting is due to attack of root and stem rotting organisms that live and feed by attacking either the aerial or under ground parts of the plant. It can be prevented by combining practices like the prevention of the root injury, maintenance of capacity of a soil by nutrient management, avoiding any haphazard use of pesticides and chemical fertilizers and adopting regular cultivation practices. A complete survey of the disease in different ecological zones is necessary to make proper evaluation of the damage caused by the wilt in the natural, irrigated plantations and all along the canals and roads. Being an economical tree of Asia, all Asian countries can have research consortium, exchange of new findings and develop a common program for the managing the disease.

The dead, wilted and die- back plants should be uprooted to check sources of the pathogens to stop further spread of the disease. Plantations on clayey and waterlogged soils should be avoided. Mixed cropping is recommended to avoid wilting. New shisham nurseries should be raised from the seeds and cuttings of the resistant variety to replace the susceptible varieties. Watering is beneficial during relatively dry autumns and during dry summer months. Use Benomyl to check wilting in young Shisham plants. Add organic materials such as farmyard manure along with some antagonistic fungi to reduce the spread of the pathogen.xchange. The work(Kumar,2014)reflects that major cause of shisham wilting is species of Fusarium. Their management is possible through mixed plantation with Putranjiva.

\section{References}

Adenusi A. A. \& Odaibo A. B 2009. Effects of varying concentrations of the crude aqueous and ethanolic. African Journal of Traditional, Complementary and Alternative medicines 6(2). 
Ahmad M, Khan MA, Ahmad F, Khan SM 1996. Effectiveness of some fungicides on the colony growth of Fusarium oxysporum and $F$. solani associated with potato wilt. Pak. J. Phytopathol., 8: 159-161.

Al-Hetar M. Y., M. A. Zainal Abidin, M. Sariah and M. Y. Wong 2011 Antifungal activity of chitosan against Fusarium oxysporum f. sp. Cubense.Journal of Applied Polymer Science 120(4): 2434-2439.

Anupama.2015.Medicinal Tree Shisham /Sissoo _ _ (Dalbergia _ _ sissoo) http://www.bimbima.com/health/post/2 $015 / 02 / 10 /$ medicinal-tree ishishamsissoo-dalbergia-sissoo aspxi

Asha Kaji, Shrestha and R.D. Tiwari 2009 Antifungal activity of crude extracts of some medicinal plants against Fusarium solani (Mart.) Sacc. Ecoprint 16:75-78.

Bagchee,K.D 1945 Pathological notes,Wilt and dieback of Sisham,babul and khair in the artificial regeneration under agriculture cum forestory management.Indian Forester 71;20-24.

Bajwa,R and Javaid A 2007 Integrated disease management to control shisham (Dalbergia sissoo roxb.) decline in pakistan.Pak. J. Bot., 39(7): 2651-2656

Bajwa, R., Javaid A, Mirza J.H and N. Akhtar 2003 Chemical control of wilt in Shisham (Dalbergia sissoo Roxb.). Mycopath, 1(2): 111-113.

Bajwa R, Javaid A, Shah MBM 2003 Extent of shisham decline in Lahore, Sialkot, Gujranwala and Sergodha districts. Mycopath, 1: 1-6.

Bakhshi, B.K 1954 Wilt of shisham (Dalbergia sissoo) due to Fusarium solani. Nature, 174: 278-291.

Baksha MW, Basak AC 2000 Mortality of sissoo in Bengladesh. In: Proceedings of the Sub-Regional Seminar on
Dieback of Sissoo in Katmandu, Nepal, 25-28, April, 2000, pp.1-4.

Bakshi BK 1957 Wilt disease of shisham II Behavior of Fusarium solani, the wilt organism in the soil. Indian Forester 81: 276-281.

Bakshi, B.K 1974 Control of root disease in plantation in reforested stands. Indian Forester, 100:77-78.

Bakshi, B.K. 1955. Wilt disease of shisham (Dalbergia sissoo Roxb.). Behaviour of Fusarium solani, the wilt organism, in soil. Indian Forester 81: 276-281.

Bakshi, B.K. 1957. Wilt disease of shisham (Dalbergia sissoo Roxb.). The effect of soil moisture on the growth and survival of Fusarium solani in the laboratory. Indian Forester 83 : 505511.

Bakshi, B.K. and Singh, S. 1954. Wilt disease of shisham. I Introduction and host parasite relationship. Indian Forester 80: 316-322.

Bakshi, BK, Singh AC 1959 Root disease ofshisham (Dalbergia sissoo). VIII. Inoculation study on wilt. Indian Forester, 85: 415-421.

Bakshi,B.K 1954 Wilt of sisham(Dalbergia sissoo Roxb.) due to Fusarium solani Snyder and Hansen.Nature 174;278279.

Bakshi,B.K and Singh,S 1959 Root disease of sisham.Indian Forester,85;415-421.

Belakssem El Amraoui, Jean François Biard, Fatima Ez-Zohra Ikbal, Majida El Wahidi, Mostafa Kandil, Mohammed El Amraoui and Aziz Fassouane 2015 Activity of Haliscosamine against Fusarium oxysporum f.sp. melonis: in vitro and in vivo analysis. SpringerPlus 4:16 doi:10.1186/s40064-015-0797-x

Bhambal, Ajay; Sonal Kothari; Sudhanshu Saxena; Manish Jain 2011 "Comparative effect of neemstick and toothbrush on plaque removal and gingival health $-\mathrm{A}$ clinical 
trial". Journal of Advanced Oral Research 2 (3): 51-56.

Bhandari M.S, Rama Kant, Nafeesh Ahmed, Shivani Dobhal R. K. Luna, S. Nautiyal Vijay Kumar, Ashok Kuma 2014 Shisham Mortality in Hoshiarpur, Punjab:Causes and Remedy.Indian Forester, 140(2).

Brasier, C.M 1975 Stimulation of sex organ formation of Phytophthora by antagonistic species of Trichoderma. I. The effect in vitro. New phytopathol., 74: 183-194.

Browne F,G 1968 Pest and diseases of forest plantation trees.1330pp Clarendon Press, Oxford.

Chaturvedi,R 1979 Evaluation of higher plants for their fungitoxicity against Helminthosporium oryzae.Ph.D Thesis Gorakhpur Uniersity,Gorakhpur,India.

Czaczyk K, Trojanowska K, Mueller A 2002 Antifungal activity of Bacillus coagulans against Fusarium sp. Acta Microbiol Pol. 51(3):275-83.

Davis D, Qaggoner PE, Diamond AE, 1953 Conjugated phenals in the Fusarium wilt syndrome. Nature, Lond. 172: 95.

Dayaram, M. Kumar, S. Sharma and O.P. Chaturvedi 2003 Shisham mortality in Bihar. extent and causes. Indian Phytopath. 56 (4) : 384-387.

Dennis, C. and J. Webster 1971 Antagonistic properties of species groups of Trichoderma II.Production of volatile antibiotics. Trans. Br. Mycol. Soc., 57: 41-48.

Elad, Y., I. Chet and J. Katan 1982 Degradation of plant pathogenic fungi by Trichoderma harzeanum. Can. J. Microbiol., 28: 719-725.

Gill MA; Ahmad I, Khan AU, Khan AU, Khan M, 2001. Phytophthora cinnamomi. A cause of shisham decline in Punjab, Pakistan. In:Proceedings of $3^{\text {rd }}$ National Conference of Plant Pathology, October, 1-3, 2001, NARC,
Islamabad, pp. 33-37.

Hajare S.W, Chandra S et al 2001 Antiinflammatory activity of Dalbergia sissoo leaves, Fitoterapia 72(2): 131139. $\quad 31$ http://Www.wood-1 idatabase.com/lumberidentification/ha

Harsh, N.S.K. (personal communication) : Shisham (Dalbergia sisoo) Mortality: Causes and Remedy. Forest Pathology Division, Forest Research Institute, Dehradun-248006. ICFRE Bulletin. ihttp:///www.icfre.org/UserFiles/File/FR' II-Files/Shisham-Note-031210.pdf

Hugar M.H, Hosamani K.M and Ahmed L 2010 Phytochemical and pharmacological studies of ethanol extract of Dalbergia sissoo seeds. An approach for the invivo analgesic and antipyretic activities. International Journal of Pharma and Bio Sciences. 1(4): 272-280.

Jasenka Ćosić, Karolina Vrandečić, Jelena Postić, Draženka Jurković, Marija Ravlić 2010 In vitro antifungal activity of essentialoils on growth of phytopathogenic fungi.Poljoprivreda 16 (2) :25-28

Javaid, A., R. Bajwa and A. Tahmina.2004 Tree dieback in Punjab, Pakistan. Mycopath, 2: 1-5.

Johnson, F \& Curl. EA 1972 Minnepolis Burgress Publishing Co. 4, 97-102.

Jun Yuan, Waseem Raza, Qirong Shen and Qiwei Huang Qiwei Huang 2012 Antifungal Activity of Bacillus amyloliquefaciens NJN-6 Volatile Compounds against Fusarium oxysporum f. sp. Cubense. Appl. Environ. Microbiol. 78(16): 59425944.

Kamel A. Abd-Elsalam, Alexei R. Khokhlov 2015 Eugenol oil nanoemulsion: antifungal activity against Fusarium oxysporum f. sp. vasinfectum and phytotoxicity on cottonseeds.Applied Nanoscience 5(2): 
255-265,

Kaur A, Singh S, Chandra P 2011. Evaluation of antioxidant potential of stem bark extract of Dalbergia sissoo. Journal of Pharmacy Research 4(10): 3439-3441.

Khan MH. 2000. Shisham die-back in Pakistan and remedial measures. In: Proceedings of the Sub-Regional Seminar on Dieback of Sissoo in Katmandu, Nepal, 25-28, April, 2001. pp. 45-50.

Khan, A. H. \& Bokhari, A. S 1970 Damage due to fungus diseases in Bhagat plantation, Lyallpur Forest Division. Pakistan Journal of Forestry 20(3): 293-311.

Khan, A. H., Asghar, A. G., Ghulam Rasul, Ch. \& Hamid, A 1965 Observation on the mortality of shisham (Dalbergia sissoo Roxb.) and other trees in Khanewal plantation. Part I, II and III. Pakistan Journal of Forestry 6 (2, 3, 4) : 109-120, 203-220 and 289-301.

Khan, M.M. and M.H.Khan 2000 Dieback of Dalbergia sissoo Roxb. in Pakistan. In: Proc. of the Sub-Regional seminar on dieback of sissoo (Dalbergia sissoo Roxb.), Katmandu, Nepal, 25-28 April 2000. pp. 51-56.

Khan, S.H., M. Idress, F. Muhammad, A. Mahmood and S.H. Zaidi. 2004 Incidence of shisham (Dalbergia sissoo Roxb.) decline and In vitro response of isolated fungus spp., to various fungicides. Int. J. of Agril. Biol., 6: 611-614.

Kharkwal H, Joshi D. D, Kharkwal A, Panthari P 2012 Anti-termite activity of heartwood of Dalbergia sissoo Roxb. Ex.Dc. Asian pacific journal of biomedicine 1(4): 23.

Kumar Narendra (2014)Search of a natural remedy for control of Fusarial wilting of Sisham(Dalbergia sissoo Roxb.).Int.J.Eng.Res.Sci. and
Tech.,3(1):34-44.

Lorito, M., G.E. Harman, C.K. Hayes and A. Dipietro 1993 Chitinolytic enzymes produced by Trichoderma harzeanum: Antifungal activity of purified endochitinase and chitobiodase.Phytopathology, 83: 302307.

Manadhar, G. and S.K. Shrestha, S. Appanah, G. Allard and S.M. Amatya. 2000 Fungi associated with dieback of sissoo. Proc., of Intl. Seminar, Nepal, (18): 27-29.

Manadhar, G. and S.K. Shrestha. 2000. Fungi associated with dieback of sissoo. In: Proc. of the Sub-Regional seminar on dieback of sissoo (Dalbergia sissoo Roxb.), Katmandu, Nepal, 25-28 April 2000. Pp 27-30

Mcwain P, Gregory GFA 1973 Benomyl derived fungitoxicant for tree wilt disease control. USDA For. Serv. Res. Note, N.E. Forest Expt. Sta. No. 162. RPP. 53, 2: 689 Abst.

Mcwain, P. and G.F.A Gregory 1973 Benomyl derived fungitoxicant for tree wilt disease control.USDA For. Serv. Res. Note, N.E. Forest Expt. Sta. No. 162. RPP. 53(2): 689 Abst.

Mohammad Asif and Arun Kumar 2009 Antiinflammatory activity of ethanolic extract of Dalbergia sissoo (Roxb.) bark. Malaysian Journal of Pharmaceutical Sciences; 7(1): 39-50.

Mohammad Asif and Arun Kumar 2011 Photochemical investigation and evaluation of antinociceptive activity of ethanolic extract of Dalbergia sissoo (Roxb.) bark. Journal of natural science, Biology and Medicine 2(1): 76- 79. 22.

Mukerjee S.K, T. Saroja \& T. R. Seshadri 1971 "Dalbergichromene: a new neoflavonoid from stem-bark and heartwood of Dalbergia sissoo". Tetrahedron 27 (4): 799-803.. 
Niranjan P.S, Singh D, Prajapati K and Jain S.K 2010 Antidiabetic activity of ethanolic extract of Dalbergia sissoo L. leaves in alloxaninduced diabetic rats. International Journal of Current Pharmaceutical Research. 2(2): 24-27.

Nitinkumar Upwar, Patel R, Waseem N 2011. Evaluation of anthelmintic activity of Dalbergia sissoo Roxb. International Journal of Pharmaceutical Sciences and Research 2(1): 171-174. 27.

Ormancy,Y.,Sissali,S and Coutiere,P 2001 Formulation of essential oils in functional perfumery.Perfumes Cosmetiques,Actualities, 157;30-40.

Parker, R. N 1918 A Forest Flora for the Punjab with Hazara and Delhi. Printed by the Superintendent, Govt. Printing Press, Lahore.plantation, Lyallpur Forest Division. Pakistan Journal of Forestry 20(3): 293-311.

Pund K.V, Vyawahare N. S, Gadakh R. T 2012. Antidiabetic Evaluation of Dalbergia sissoo against alloxan induced diabetes mellitus in wistar albino rats. J. Nat. Prod. Plant Resour. 2 (1): 81-88.

Rajput P N.A, M.A. Pathan, M.M. Jiskani, A.Q. Rajput AND R.R. Arain 2008 Pathogenicity and host range of Fusarium solani (MART.) sacc. causing dieback of shisham (Dalbergia sissoo Roxb.). Pak. J. Bot., 40(6): 2631-2639,

Rosado-Álvarez C, L. Molinero-Ruiz' R. Rodríguez-Arcos, M.J. Basallote-Ureba 2014 Antifungal activity of asparagus extracts against phytopathogenic Fusarium oxysporum.Scientia Horticulture 171:51-57.

Rukhsana Bajwa and Arshad Javaid 2007 Integrated disease management to control shisham (Dalbergia sissoo Roxb.)decline in Pakistan. Pak. J. Bot., 39(7): 2651-2656.
Sawamura,M 2000 Aroma and functional properties of Japanese yuzu(Citrus junos Tanaka) essential oil.Aroma Research 1;14-19.

Shakir AS, Khan SM and Ahmad R, Shakir AS, Khan SM and Ahmad R 1999 First report on shisham decline in Pakistan. Pak. J. Phytopathol, 11: 106.

Sharma B, Kumar P 2009 In vitro antifungal potency of some plant extracts against Fusarium oxysporum. Int Pharm3:63:http://www.greenpharmacy, info/text.asp?2009/3/1/63/49377,

Sharma MK, Singal RM, Pokhriyal TC 2000 Dalbergia sissoo in India. In: Proceedings of the Sub-Regional Seminar on Dieback of Sissoo in Katmandu, Nepal, 25-28 April, 2000. pp. 5-17.

Shazia Sultana, Mir Ajab Khan, Mushtaq Ahmad and Muhammad Zafar 2006 Indigenous Knowledge of Folk Herbal Medicines by the Women of District Chakwal, Pakistan. Ethnobotanical Leaflets 10: 243-253.

Sibounnavong P Sibounnavong P S Kanokmedhaku S and Soytong, K 2012 Antifungal activities of Chaetomium brasilense CB 01 and Chaetomium cupreumv $\mathrm{CC} 03$ against $\mathrm{F}$. oxysporum f. sp. Lycopersici race 2. Journal of Agricultural Technology 8(3): 10291038

Sidana J.K, Saini V and Dahiya S 2012 Analgesic and anti-inflammatory activities of Dalbergia sissoo leaves extract. International journal of natural product science; Spl Issue 1: 134.

Sirirat Siripornvisal 2010 Antifungal Activity of Ajowan Oil against Fusarium oxysporum. KMITL Sci. Tech. J. 10 (2):45-51.

Taiz, L. and E. Zeiger 1991 Plant Physiology. The Benjamin/Cummings Publishing Co., Inc. Redwood City, 
CA.

Tariq Riaz, Salik Nawaz Khan and Arshad Javaid 2008 Antifungal activity of plant extracts against Fusarium oxysporum - the cause of corm-rot disease of Gladiolus.Mycopath 6(1\&2): 13-15

Tewari, D. N 1994 A monograph on Dalbergia sissoo. Intern. Book Distributors 9/3, Rajpur Road, Dun.

Tongbram Ranjana Devi and GKN Chhetry 2012 Evaluation of antifungal activities of certain plant against Fusarium udum Butler causing wilt in pigeonpea (Cajanus cajan(L.) Millsp.) International Journal of Scientific and Research Publication 2(6):1-4

Tripathi N.N and Narendra Kumar 2007
Putranjiva roxburghii oil-A potential herbal preservative for peanuts during storage.Journal of stored Products Research,43;435-442.

Troup, R. S. 1921. The Silviculture of Indian Trees 1, Oxford (Rev. Edition 1980).

Veihmeyer, F.J. and Hendrickson, A.H1928 "Soil moisture at permanent wilting of plants". Plant Physiol. 3 (3): 355-357. doi:10.1104/pp.3.3.355.

Zakaullah, 1999 Shisham decline in Pakistan. Plant diseases of economic importance and their management, pp: 12. Proc. the Second National Conf. Plant pathology organised by Pakistan Phyto. Path. Soc. UAF.

\section{How to cite this article:}

Narendra Kumar and Paul Khurana S. M. 2016. Bio Management of Wilting of a Valuable Timber and Medicinal Plant of Shisham (Dalbergia sissoo Roxb.) - A Review. Int.J.Curr.Microbiol.App.Sci. 5(1): 32-54. doi: http://dx.doi.org/10.20546/ijcmas.2016.501.004 